\title{
Preventive Practices from Field and Shelf to Fork to Minimize Chemical Hazards Dietary Intake
}

\author{
Vassiliki T Papoti ${ }^{1^{*}}$, loannis Mourtzinos ${ }^{2}$ and \\ Tryfon Adamidis ${ }^{1}$ \\ ${ }^{1}$ Department of Food Science \& Technology, Perrotis College, \\ American Farm School, Thessaloniki, Greece \\ ${ }^{2}$ Department of Food Science \& Technology, Faculty of Agriculture, \\ Aristotle University of Thessaloniki, Greece \\ *Address for Correspondence \\ Vassiliki T Papoti, Department of Food Science and Technology, Perrotis \\ College, American Farm School, Marinou Antipa 54, Thessaloniki, Greece, \\ Tel: +30 2310492 826; E-mail: vpapot@afs.edu.gr \\ Submission: 12 September, 2016 \\ Accepted: 14 October, 2016 \\ Published: 25 October, 2016 \\ Copyright: () 2016 Papoti VT et al. This is an open access article \\ distributed under the Creative Commons Attribution License, which \\ permits unrestricted use, distribution, and reproduction in any medium, \\ provided the original work is properly cited.
}

food professionals and food handlers is lacking, even on countries that possess advanced food safety systems and strict food legislation. Besides, financial difficulty reinforces people to utilize low quality food and houseware increasing the health related hazards. Regarding the severity for global health and damage costs, the need for information on precautionary practices that will reduce chemical hazards dietary intake is imperative. In the present review certain practices such as thermal processing, washing or appropriate handling of the raw material are listed to educate anyone related with the food sector how to minimize heavy metals, acrylamide, pesticides residues, heterocyclic aromatic amines and polycyclic aromatic hydrocarbons intake and promote health. The introduced simple practices can be applied except for home kitchens, also in quality systems of professiona kitchens, warehouses and food industries.

\section{Introduction}

It is widely known that there is an unquestionable link between nutrition and health. Additionally, the higher living standards along with frequent food safety incidents have increased consumers concern for safer and healthier foodstuffs. Although efforts are being made to improve food safety and quality the number of related risks remains very high, resulting in considerable costs to individuals, industries, communities and economies [1-3]. The latter applies even to countries that possess advanced food safety systems and strict food legislation $[2,4]$. On the other hand, people in developing countries are exposed to higher food safety risks due to uncontrolled environmental pollution and circulation of "suspect" foodstuffs, in addition to lack of knowledge on food safety issues [5]. Besides, in 2016 there still exist risks for severe water born diseases due to poor sanitation and poor access to safe drinking water (e.g. in some West African countries) [6]. The magnitude of human suffering and economic losses cannot be accurately determined as many cases are unreported and many outcomes of new food hazards have not emerged yet [2].

Data reveal that there are worldwide important knowledge gaps even for simple food related issues concerning handling, hygiene and safety $[1,2,4,5]$. On the other hand, matters related to food associated hazards are quickly changing, with new "chemical poisons" to place serious health risks. In addition, financial difficulties reinforce people to utilize low quality food and houseware introducing safety issues. Relative knowledge is absent not only for the public, but also among food handlers and professionals. Most hazards are more dangerous for vulnerable individuals such as pregnant and breastfeeding women, prenatal, natal and early childhood $[7,8]$. The latter are very susceptible to chemical threats, as being in early development and having a dietary pattern (higher food intake per kg body weight) that differs notably from that of adults [9].

Although hazards accumulation is associated among others to toxicity, carcinogenicity, neurodegenerative, cardiovascular and autoimmune disorders it is difficult to directly link certain foods or certain harmful chemicals intake with the cause of a disease. In general, the severity of the harm is related to the properties of the contaminant, its concentration in the foodstuff and the frequency of human exposure to it. The co-intake of other substances and other parameters such as heredity, physical activity, lifestyle significantly affect the overall human health [10]. However, the intake of harmful chemicals is widely accepted to negatively contribute to human status and therefore it is vital to be minimized [11]. Therefore, circulation of relevant information is imperative.

Numerous scientific papers and reviews on analytical issues, chemical, biological, health and medicinal aspects of chemical hazards exist. However, no preventive actions for hazards minimization, applicable in every sector where food is handled, are summarized. The aim of this review is to present precautionary practices for everyone implicated in the food chain that consumes, produces and/or handles food, so as selected chemical hazards intake to be decreased for a healthier wellbeing. The introduced simple practices can be also incorporated in quality systems of professional kitchens, warehouses and food industries. From the plethora of food related hazards, this review addresses to the harmful heavy metals, acrylamide, pesticide residues, heterocyclic aromatic amines and polycyclic aromatic hydrocarbons.

\section{Harmful metals dietary intake prevention}

Heavy metals have been related with toxicity, carcinogenicity, abnormalities in early childhood, neurodegenerative disorders, 
Citation: Papoti VT, Mourtzinos I, Adamidis T. Preventive Practices from Field and Shelf to Fork to Minimize Chemical Hazards Dietary Intake. J Nutri Health. 2016;2(2): 12.

ISSN: $2469-4185$

undesirable metabolic actions, kidney, bone and gastrointestinal damages, cardiovascular diseases and other acute and chronic illnesses [12-16]. They mainly accumulate in blood, kidney and liver causing deleterious effects on human health [12]. Individuals may be exposed to metals through the environment, as well as cookware, food, water, medicines, and products of personal care. The major concern regarding toxic metals intake is related to food contact materials, though strict regulations exist and firm limits are established by official bodies for the leaching of harmful metals from food contact materials. Ordinarily, food originated metal toxicities are not frequent under regular conditions [12,17]. Still, Joint FAO/WHO and EC Committees established maximum limits for the presence of some toxic metals (Cd, $\mathrm{Pb}, \mathrm{Hg}$ and $\mathrm{Sn}$ ) in certain foodstuffs (Commission Regulation EC No 1881/2006).

\section{Exposure related to food contact materials}

Regarding Europe, materials that are intended to come in contact with food should comply with the regulation EC No 1935/2004 and the maximum limits set by the council directives (e.g. Directive 84/500/ EEC for ceramics). Still, the number and frequency of notifications recorded in the Rapid Alert System for Food and Feed (RASFF) concerning heavy metals (mainly $\mathrm{Mg}, \mathrm{Ni}, \mathrm{Pb}, \mathrm{Cr}, \mathrm{Cd}$ ) migration from food contact materials indicate the magnitude of declination from the norms. Low quality houseware have overwhelmed international markets, as financial difficulties reinforce people to seek for inexpensive alternatives. Notified materials, mainly originated from China, include among others oven trays, coffee percolators, tea and other strainers, toasters, knives, spoons and forks, scissors, electric oven and barbecue grids and sets, baking dishes, ceramic plates and mugs, porcelain and other tableware, kitchen utensils, colored and decorated glasses, enamel fondue sets, microwave ovens, woks and frying pans.

Frequently, risk from food contact materials is related to public ignorance and traditional habits. Consumers are unaware that the use of crystal glasses and decanters, as well as glazed ceramic and earthenware equipment is a severe risk for lead toxicity. In certain communities (e.g. African and Asian countries) significant amounts of toxic metals are frequently ingested by consumption of beverages from traditional pots [18]. The risk is serious if such dishware are frequently used for the consumption of hot or acidic beverages or addressed to pregnant woman and small children [7,18-20].

Metals (mainly $\mathrm{Al}, \mathrm{Fe}, \mathrm{Cr}, \mathrm{Ni}, \mathrm{Cd}, \mathrm{Sn}, \mathrm{Pb}, \mathrm{Cu}$ ) may migrate from cookware, utensils, containers and packaging materials (such as cans and wrapping foils) [21,22] One of the most frequent and severe risks is related to aluminum, as it is related to serious neurogenerative disorders (e.g. Alzheimer). Levels of metals (usually $\mathrm{Al}, \mathrm{Cd}, \mathrm{Sn}, \mathrm{Pb}$ and $\mathrm{Cu}$ ) in canned foods are reported to be higher than that of uncanned relevant products [23]. Concentrations are usually reported to be acceptable for human consumption [24-26]. Still, canned foods in some cases exceed tolerable limits. Last but not least, various inorganic elements $(\mathrm{Al}, \mathrm{As}, \mathrm{Ba}, \mathrm{Br}, \mathrm{Ca}, \mathrm{Cd}, \mathrm{Co}$, $\mathrm{Cr}, \mathrm{Cu}, \mathrm{Fe}, \mathrm{Hg}, \mathrm{Ni}, \mathrm{Pb}, \mathrm{Sb}, \mathrm{Sn}, \mathrm{Se}, \mathrm{Ti}, \mathrm{Zn}$ etc.) contained in plastic containers to enhance quality may contaminate food through containers' degradation [27]. Metals migration is favored under low or high $\mathrm{pH}$ conditions [22]. Among the factors that may enhance migration are high temperatures, the available oxygen, the presence of nitrites, un-lacquered or poorly lacquered cans, the quality, age and previous use of the material, duration of contact (long storage or prolonged cooking), and presence of salt, sugar and some ions (e.g. F, $\mathrm{Cl}, \mathrm{CO}_{3}$ ) [27-30]. In Table 1 precautionary practices for minimizing harmful metal intake from migration from food contact materials are summarized.

\section{Exposure related to food}

Metals occur in all foodstuffs, and their content is influenced by many factors including environmental conditions (contaminated soils and/or atmospheres, aquatic conditions), the nature and part of the foodstuff, post-harvest treatments, processing, and kitchen practices [31]. In addition drinking and cooking water can be contaminated with heavy metals due to the poor quality of the water source, the use of chemicals for the water treatment or the leaching of metals from pipeline materials [32]. As shown by literature and RASFF portal notifications the most metal burdened foodstuffs are fish, cephalopods and related products, followed by canned products, leafy and root vegetables, fruits, cocoa and coffee. The origin of the foods with harmful metals (mainly $\mathrm{Hg}, \mathrm{Cd}$ and $\mathrm{Pb}$ ) in levels above the

Table 1: Overview of precautionary practices for minimizing harmful metal intake from migration from food contact materials.

\begin{tabular}{|c|c|}
\hline Precautionary practice & Reference \\
\hline $\begin{array}{l}\text { Prolonged preparation and long term storage of acidic, alkaline, salty foods and drinks in cans, } \\
\text { aluminum, steel, metallic containers, and relevant vessels, cookware and packages should be } \\
\text { avoided; low temperature }\left(\text { e.g. } 5^{\circ} \mathrm{C} \text { ) storing conditions should be preferred. }\right.\end{array}$ & {$[22,26,28-30,106-108]$} \\
\hline $\begin{array}{l}\text { Aluminum foil to wrap acidic, salty or fluoride containing food products upon cooking should not be } \\
\text { used; high temperatures, prolonged cooking and prolonged storage should be avoided. }\end{array}$ & {$[29,109]$} \\
\hline Boiled water of first use from new cookware should be thrown away. & [106] \\
\hline $\begin{array}{l}\text { Wrapping foils, containers, cookware, utensils and packaging papers, only of materials appropriate } \\
\text { for contact with foods, that bear the respective signs should be used; use should be according to } \\
\text { manufactures suggestions and directions. }\end{array}$ & {$[27,110,111]$ Regulation EC No 1935/2004 } \\
\hline Good grade plastic containers should be used, and their often replacement is strongly suggested. & [27] \\
\hline $\begin{array}{l}\text { Frequent consumption of alcoholic and acidic beverages from crystal glasses and decanters should } \\
\text { be avoided; consumption of long term stored beverages in crystal decanters should be avoided. }\end{array}$ & {$[112,113]$} \\
\hline $\begin{array}{l}\text { Care should be given with glazed earthware, porcelain and ceramics that should not be used } \\
\text { for regular food consumption, preparation, serving, and storage, especially for acidic and/or hot } \\
\text { foodstuffs and beverages; use of porcelain, ceramic dinnerware and metallic teapots of questionable } \\
\text { origin and quality should be avoided. }\end{array}$ & {$[7,16,19,20,114]$ Directive 84/500/EEC [18] } \\
\hline
\end{tabular}


Citation: Papoti VT, Mourtzinos I, Adamidis T. Preventive Practices from Field and Shelf to Fork to Minimize Chemical Hazards Dietary Intake. J Nutri Health. 2016;2(2): 12.

ISSN: 2469-4185

Table 2: Overview of precautionary practices for minimizing harmful metal intake.

$$
\text { Precautionary practice }
$$

Fruits, vegetables, cereals, spices, herbs, medicinal plants, marine products and other foodstuffs from unquestionable sources and [17,34,37,52,115,116] contaminated environments (e.g. near to highways, industries, mines, contaminated aquatic environments) should be avoided

Rice should be washed until clear and cooked in excess of water that will be discarded after cooking.

$[26,107,117,118]$

Regular consumption of canned food and drinks should be avoided; long term storage of canned products should be avoided; canned products should be stored at low temperatures either at home or at storehouses of producers, distributers and selling points.

Regular consumption of large size marine species, swordfish, shark, tuna, marlin, lobster, mussels, cuttlefish, squid, crabs, shellfish,

$[24,26,28,107]$

Regular consumption of large size marine species, sword
mollusks, shrimps and relative products should be avoided.

When consuming edible crab, muscle than brown meat should be preferred.

$[8,16,31,47,119]$

Fish fillets should be dipped in a salt solution (e.g. $0.5 \% \mathrm{NaCl}$ for $\sim 15 \mathrm{~min}$ ) prior cooking

Co-ingestion of green tea, black tea or coffee with fish meals is strongly suggested.

Frequent consumption of visceral parts should be avoided; visceral parts should be removed prior food processing.

A broad variety of foodstuffs should be consumed; various modes of cooking should be employed.

Uncontaminated water should be used for drinking and cooking; Before water for cooking and drinking is collected the tap should be flushed and an appropriate filtration unit should be employed; Consumption of products cultivated by contaminated or questionable quality water should be avoided.

Recipes including the use of acidic means (such as vinegar, lemon juice) during cooking of meat coming from hunt, should be avoided.

Fruits and vegetables should be thoroughly washed before consumption.

The skin of fruits and vegetables should be peeled off.

$[122,125]$

allowable is mainly Asian countries. In many cases data from market basket surveys for heavy metals burden are reassuring [33]. Still, in several parts of the world (e.g. Asia, Pakistan, Nigeria, China, New Zealand, Saudi Arabia), heavy metals levels of products designated for human consumption are worryingly high $[17,34]$.

Environmental pollution significantly burdens food chain $[17,35]$. Leafy and root vegetables, as well as rice, seem to be more susceptible to metal accumulation [36,37]. Groundwater contamination with heavy metals is an important issue in several regions of Asia. The latter leading to contaminated rice is viewed as a disaster for habitants of these areas due to the quantity and frequency of its consumption in their diet $[36,37]$. Besides, other factors, such as urban agriculture, irrigation of cultivated hectares with untreated wastewaters, industrial and municipal pollution, traffic emission and mining, may seriously contaminate vicinal food products $[17,35,38,39]$.

Several published studies on how cooking practices affect metal levels in fish and seafood are available [40-47]. Still, findings are conflicting. The effect of cooking seems to depend upon the metal tested, cooking conditions employed (time, temperature, practice), the part, size and nature of the food, and the presence of other ingredients. Alteration of metal concentration has been related among others to the different bioaccumulation and chemical feature of each metal, water and fat loss, protein degradation, oil uptake and possible interactions with other constituents present $[40,42,48,49]$. In many cases cooking is shown to increase metal concentrations in cooked and processed fish and seafood $[40,45,47,49]$. Even though based on current knowledge general suggestions on cooking practices to minimize harmful metals intake cannot be given $[41,44]$, cooking seems to positively affect metals bioaccessibility [50]. Recent data concerning experiments conducted on cooked tuna, shark and mackerel showed that the cooking procedure significantly reduced $\mathrm{Hg}$ bioaccessibility (40 and $60 \%$ for frying and boiling, respectively). Moreover, the co-ingestion of tea or coffee may lead to low levels of metals bioaccessibility $[46,51]$.

On the other hand, traditional and therapeutic herbs with recent entry to the food sector (e.g. herbal beverages, functional products enriched with herbal extracts or essentials oils) have reports for toxic metals and other chemical poisons (e.g. pesticide residues) in alarming levels revealing the intense need for strict controls towards this direction $[34,52,53]$. An overview of precautionary practices and suggestions for minimizing dietary harmful metal intake can be found in Table 2.

\section{Acrylamide dietary intake prevention}

Acrylamide (AA) is a colorless, odorless and crystalline solid with a melting point of $84.5^{\circ} \mathrm{C}$. It is formed by hydration of acrylonitrile and it is soluble in water, acetone and ethanol. It is a biodegradable compound and exhibits high mobility in soil and groundwater [54]. It can be found in carbohydrate-rich foods that have been heated to temperatures above $120^{\circ} \mathrm{C}$, and it is one of the products of the Maillard reaction between free asparagines and reducing sugars (primarily glucose and fructose). Thermal treatment such as baking, frying and roasting favor its formation. Potatoes and cereals are

Table 3: Acrylamide (AA) content ( $\mathrm{g} / \mathrm{kg}$ ) of various foodstuffs.

\begin{tabular}{|c|c|}
\hline Foodstuff & (AA) $\mathrm{g} / \mathrm{kg}$ \\
\hline Fried potato & $272-570$ \\
\hline Bakery products & $75-1044$ \\
\hline Breakfast cereals & 149 \\
\hline Coffeea & $229-890$ \\
\hline
\end{tabular}


Citation: Papoti VT, Mourtzinos I, Adamidis T. Preventive Practices from Field and Shelf to Fork to Minimize Chemical Hazards Dietary Intake. J Nutri Health. 2016;2(2): 12.

ISSN: 2469-4185

Table 4: Overview of precautionary practices for minimizing acrylamide intake.

\begin{tabular}{|c|c|}
\hline Precautionary practice & Reference \\
\hline $\begin{array}{l}\text { Temperatures above } 175^{\circ} \mathrm{C} \text { should be avoided as formation of acrylamide proceeds with lower rate at temperatures below } \\
175{ }^{\circ} \mathrm{C} \text {. } \\
\text { In general the formation of acrylamide increases with temperature, whereby at temperatures between } 150 \text { and } 170{ }^{\circ} \mathrm{C} \text { the } \\
\text { rate is relatively low, while at temperatures } 180 \text { and } 220^{\circ} \mathrm{C} \text { the rate is higher. A temperature of } 175^{\circ} \mathrm{C} \text { can be considered as } \\
\text { an upper limit for frying. This value of temperature is the temperature that has been agreed between food industry and food } \\
\text { authorities in Germany. }\end{array}$ & [126-128] \\
\hline $\begin{array}{l}\text { Cooking time has a linear effect on acrylamide formation at a given temperature thereby frying time should be as short as } \\
\text { possible to prepare organoleptic accepted food. Overcooking should be avoided. }\end{array}$ & {$[127,129]$} \\
\hline $\begin{array}{l}\text { Potatoes are suggested to be stored between } 8-10^{\circ} \mathrm{C} \text { in order to prevent excessive enrichment of reducing sugars. Storage } \\
\text { of potatoes at } 2{ }^{\circ} \mathrm{C} \text { results in increased free sugar content that is converted to higher acrylamide levels during cooking as } \\
\text { compared with potatoes stored at higher temperatures. }\end{array}$ & {$[130,131]$} \\
\hline $\begin{array}{l}\text { Blanching and soaking can remove asparagine and reducing sugars, diminishing thus acrylamide content in the final foodstuff. } \\
\text { An effective way to diminish AA in food is the reduction of asparagine and reducing sugars, precursors of AA, in the raw } \\
\text { materials. Lower level of asparagine in potatoes can be achieved by blanching and soaking. The disadvantage of this method } \\
\text { is that other valuable water-soluble compounds like vitamins can be lost. The effect of blanching and soaking strongly depends } \\
\text { on the period of application, temperature, } \mathrm{pH} \text {-value, and added compounds. Asparagin can be also diminished by using } \\
\text { asparaginase, which transforms asparagine to aspartic acid from. Asparaginase has been effective tested to baked products. }\end{array}$ & {$[132,133]$} \\
\hline $\begin{array}{l}\text { Use of acidic solutions can diminish acrylamide. } \\
\text { Maillard reaction is } \mathrm{pH} \text { dependent and reduction of acrylamide formation can be achieved by soaking in acidic solution. } \\
\text { Potatoes can be soaked with citric acid solution of } 10 \mathrm{~g} / \mathrm{L} \text { for an hour. Soaking }\left(60 \mathrm{~min} \text { at } 20^{\circ} \mathrm{C}\right) \text { of potato crisps in acetic acid } \\
\text { solution prior to frying results in a } 90 \% \text { decrease in AA level. }\end{array}$ & {$[132,134]$} \\
\hline $\begin{array}{l}\text { Treatment with solutions of salts can diminish acrylamide. } \\
\text { A technique that can be applied both in industries and in kitchen is the dipping of potatoes in salt solutions of } 1-5 \% \mathrm{NaCl} \text { or } \\
20 \% \mathrm{CaCl}_{2} \text { for } 20 \text { min prior to cooking. A reduction of } \sim 60 \% \text { on } \mathrm{AA} \text { has been observed after immersion }\left(25{ }^{\circ} \mathrm{C} \text { for } 5 \mathrm{~min}\right) \text { of } \\
\text { potatoes in } 1 \% \mathrm{NaCl} \text { solution. }\end{array}$ & [135-137] \\
\hline $\begin{array}{l}\text { Acrylamide formation can be avoided with addition of antioxidant rich natural products (herbs, spices, fruits and vegetables) } \\
\text { during cooking. } \\
\text { Several natural antioxidants such as gallic acid, protocatechuic acid or herbs and foods rich in antioxidants like cumin, star } \\
\text { anise, rosemary, thyme, oregano or virgin olive oil are found to reduce AA formation during frying. Also fruit extracts rich in } \\
\text { polyphenols such as apple and red fruits have been found to inhibit AA formation. Based on these results fruits, herbs and } \\
\text { spices with known antioxidant activity can be added during cooking in order to reduce AA formation. }\end{array}$ & [138-142] \\
\hline Acrylamide formation can be decreased when carbohydrate rich food is covered (e.g. with egg) during frying. & [129] \\
\hline $\begin{array}{l}\text { Manufactures have recently applied alternative methods of frying such as flash frying (high temperature, short time), frying } \\
\text { under increased air pressure or frying followed by forced cooling that can result in acrylamide free products. Vacuum frying } \\
\left(118-140^{\circ} \mathrm{C}\right) \text { almost eliminates acrylamide formation in potato chips giving a desirable color comparable to that resulting by } \\
\text { the application of the traditional method. }\end{array}$ & {$[143,144]$} \\
\hline
\end{tabular}

the most common examples of AA contained products. AA can be also found in meat products such as burgers and coffee [55]. Table 3 presents the $\mathrm{g} / \mathrm{kg}$ of AA found in different foods according to the European Food Safety Authority (EFSA). The presence of AA in foods was first reported in 2002 from the Swedish National Food Administration [56].

$\mathrm{AA}$ is known as a neurotoxic, potential carcinogen, and mutagenic agent. The International Agency for Research on Cancer (IARC) has classified acrylamide in Class $2 \mathrm{~A}$ as probable human carcinogen [57]. It has a tendency to bind with hemoglobin forming adducts, reducing the surface for oxygen transportation to fetal organs and leading to damage of tissue cells [58]. The Joint Expert Committee on Food Additives (JECFA) of the World Health Organization (WHO) evaluated the most sensitive adverse non-carcinogenic effect to be the morphological changes in nerves of rats with a no-observed-adverseeffect level (NOAEL) of $0.2 \mathrm{mg} / \mathrm{kg}$ per day [59]. Fortunately AA levels in foods follow a clear, significant downward trend from 2002 to 2011 [60]. Thermal processing applied from individual households to food industries is an important treatment for the development of organoleptic properties such as color, taste and texture. Therefore, formation of acrylamide is frequently unavoidable as in baked and fried products maillard reaction, necessary for the development of a pleasant aroma, acquires thermal treatment. Factors that affect acrylamide formation are presented in Table 4. In general, thermal treatment conditions, pretreatment of the raw material and use of antioxidants, among others, have a strong influence on acrylamide formation.

\section{Pesticide residues dietary intake prevention}

Agricultural products are prone to weeds, insect and disease attacks, so pesticides are widely used in modern conventional farming to improve yields and products' quality [61,62]. However, despite their many advantages, pesticides are considered of the most dangerous environmental pollutants as they present stability, ability to bioaccumulate and toxicity, while they also increase resistance to pathogens and pests $[63,64]$. They are a diverse group of chemical compounds, structurally divided into inorganic and organic compounds; with the latter being more widely employed. Organochlorines, organophosphorates, carbamates, and pyrethroids are extensively used among others [63,64]. Pesticides are linked to neuro- and hypato- toxicity, reproductive disorders, disruption of hormonal and enzymatic regulation, several types of cancer and other chronic diseases $[65,66]$. They may burden consumers mainly through the consumption of fresh, raw and unprocessed conventionally cultivated vegetables and fruits.

Numerous studies deal with the estimation of pesticides exposure 
Citation: Papoti VT, Mourtzinos I, Adamidis T. Preventive Practices from Field and Shelf to Fork to Minimize Chemical Hazards Dietary Intake. J Nutri Health. 2016;2(2): 12.

ISSN: $2469-4185$

Table 5: Overview of precautionary practices for minimizing pesticide residues intake.

\begin{tabular}{|c|c|}
\hline Precautionary practice & Reference \\
\hline Consumption of organic products leads to lower intake of pesticides. & {$[61,62,69]$} \\
\hline $\begin{array}{l}\text { For drinking and cooking pesticides free water should be employed; questionable quality water should be avoided and } \\
\text { before water for cooking and drinking is collected an appropriate filtration unit should be employed (e.g. activated carbon); } \\
\text { Consumption of products cultivated by questionable quality water should be avoided. }\end{array}$ & {$[145,146]$} \\
\hline $\begin{array}{l}\text { Washing removes water soluble pesticides; } \% \text { removal depends on the type of food, the type of pesticide, the type and } \\
\text { concentration of washing medium and soaking time. } \\
\text { Washing with tap water decreases pesticide residues in most cases in a small to medium extend. Washing cabbage with } \\
\text { tap water for } 20 \text { min showed a } 18 \%, 17 \%, 19 \% \text {, and } 15 \% \text { loss in chlorpyrifos, p,p-DDT, cypermethrin and chlorothalonil, } \\
\text { respectively. } \\
\text { Washing cucumber with tap water for } 20 \text { min showed } 54 \%, 33 \%, 52 \%, 27 \% \text { and } 63 \% \text { reduction in the trichlorfon, dimethoate, } \\
\text { dichlorvos, fenitrothion and chlorpyrifos, respectively. } \\
\text { Washing of olives in mills prevented the presence of herbicide residues in the produced oil. } \\
\text { Washing with neutral, acidic or alkaline solutions (e.g. sodium chloride, radish, acetic acid, citric acid, ascorbic acid, sodium } \\
\text { carbonate, sodium bicarbonate) results in a higher removal of pesticides in relation to washing with tap water; reduction may } \\
\text { be even complete. } \\
\text { Washing potato tubers with a } 10 \% \text { acetic acid solution and a } 10 \% \text { sodium chloride solution was shown to result in a } 60-98 \% \\
\text { and } 40-90 \% \text { pesticide residue (HCB, lindane, ppDDT, dimethoate, primiphos-methyl, malathion) reduction, correspondingly. } \\
\text { The } \% \text { reduction gets higher with increase of detergents solution's concentration. } \\
\text { Washing tomatoes with } 2 \% \text { or } 10 \% \text { acetic acid solution resulted in a } 12 \text { or } 51 \% \text { reduction of the HCB pesticide. } \\
\text { A gradual pesticides reduction takes place when soaking time is increased at the same washing solution's concentration. } \\
\text { Trichlorfon decreased from cucumber in a percent of } 24 \% \text { or } 63 \% \text { after } 5 \text { or } 20 \text { min washing with } 2 \% \text { NaCl. }\end{array}$ & {$[147-154]$} \\
\hline $\begin{array}{l}\text { Peeling may result in a significant percent reduction that can reach even } 100 \% \text { in many cases (avocado, bananas, citrus, } \\
\text { kiwifruit, mango, pineapple, potatoes) as several pesticides are accumulated to the outer part of several products. } \\
\text { Peeling mango completely removed the examined pesticides (dimethoate, fenthion, cypermethrin, fenvalerate); peeling } \\
\text { tomatoes led to } 81-89 \% \text { reduction of the organochlorine (HCB, lindane, p.p-DDT) and the organophosphorous (dimethoate, } \\
\text { profenofos, pirimiphos-methyl) pesticides examined. } \\
\text { Juicing that excludes pulp, core and skin results in a substantial decrease of lipophilic residues in the final formulation. } \\
\text { Juicing of tomatoes led to } 73-78 \% \text { reduction of the organochlorine (HCB, lindane, p.p-DDT) and the organophosphorous } \\
\text { (dimethoate, profenofos pirimiphos-methyl) pesticides examined. }\end{array}$ & \\
\hline $\begin{array}{l}\text { Upon beverage preparation a partial transfer of residues takes place to the final formulation due to the low solubility of some } \\
\text { pesticides in water and their intense binding to organic matter. }\end{array}$ & {$[162,163]$} \\
\hline $\begin{array}{l}\text { Thermal treatment, cooking, boiling, blanching, home canning, significantly contribute to pesticide residues removal due to } \\
\text { volatilization, evaporation, hydrolysis and thermal breakdown of pesticides. Removal dissipation can reach } 100 \% \text { in certain } \\
\text { cases. } \\
5 \text { min stir frying of cabbage at } 100{ }^{\circ} \mathrm{C} \text { removed the } 68-87 \% \text { of pesticides (chlorpyrifos, p,p-DDT, cypermethrin, chlorothalonil); } \\
\text { home canning of tomatoes }\left(30 \mathrm{~min}, 100{ }^{\circ} \mathrm{C} \text { ) led to a } 31-82 \% \text { residue (HCB, lindane, p.p-DDT, dimethoate, profenofos, }\right. \\
\text { pirimiphos-methyl) reduction. }\end{array}$ & {$[69,147,150-152,154,156-158,164]$} \\
\hline $\begin{array}{l}\text { Storing and preserving (at room temperature, in refrigerator, in fridge) leads in pesticides reduction in a smaller or higher extend } \\
\text { depending on the type of food, the type of pesticide and conditions employed (time, temperature). } \\
\text { Reduction of pesticides residues (trichlorfon, dimethoate, dichlorvos, fenitrothion and chlorpyrifos) in cucumber stored at } 25 \\
{ }^{\circ} \mathrm{C} \text { for } 48 \mathrm{~h} \text { was } 83-98 \% ; 11-33 \% \text { reduction of the examined pesticides (HCB, lindane, p.p-DDT, dimethoate, profenofos, } \\
\text { pirimiphos-methyl) was observed in tomatoes after freezing for } 12 \text { days and } 3-4 \% \text { residue (chlorpyrifos, p,p-DDT, cypermethrin, } \\
\text { chlorothalonil) reduction after } 48 \mathrm{~h} \text { refrigeration of cabbage. } \\
\text { The longer the storing period the higher the reduction of pesticides. } \\
\text { Trichlorfon was reduced } 20 \% \text {, and } 61 \% \text { from cucumber after } 12 \text {, and } 48 \mathrm{~h} \text { storing at } 4{ }^{\circ} \mathrm{C} \text { respectively. }\end{array}$ & {$[147,149,157,165]$} \\
\hline $\begin{array}{l}\text { Ozone application in fruits and vegetables enhance pesticide residue removal; treatment conditions should be individually } \\
\text { determined for ensuring efficiency. }\end{array}$ & {$[166,167]$} \\
\hline
\end{tabular}

through food consumption with frequent results to indicate minor exposure $[9,67]$. Additionally, other data imply that chronic intake of pesticides via food consumption, total dietary, residential and occupational exposure throughout lifespan may have detrimental impact on human health $[9,66,67]$. There is a great concern for chronic toxicity to consumers of developing countries and lowincome population $[63,64,68-72]$. Therefore, considering the possible threat to human health, their use is subject to regular monitoring and continuing reassessment. Maximum residue levels (MRLs) in food products and drinking waters have been set by official bodies to secure food safety and to control international trade, with baby foods to bear even lower MRLs. At least in developed countries, pesticides MRLs are harmonized to official legislations [9]. Still, some pesticides largely exceed the MRLs given by official regulation systems, banned compounds are still being used and several cases are constantly notified at the RASFF system $[9,67]$. Notification of border rejection due to pesticide residues to overcome the set MRLs are constantly applied mainly to fruit and vegetables that usually come from Asian and African countries.

Organic products have met wide acceptance and demand, since they are considered safer and healthier compared to conventional counterparts. Still, they are not necessarily free of synthetic chemicals $[61,62,73]$ and contaminants (e.g. heavy metals, dioxins, polychlorinated biphenyls, mycotoxins) $[61,74]$ and their qualitative, nutritional and sensory superiority has not been yet clearly proved [75-78]. Nonetheless, organic products consumption is one way to minimize synthetic pesticides residue intake. However, the latter stands only if the foodstuffs are not only by "name" organic, since related products are the target for many frauds. Minimizing synthetic chemicals intake is considered of major importance especially if 
Citation: Papoti VT, Mourtzinos I, Adamidis T. Preventive Practices from Field and Shelf to Fork to Minimize Chemical Hazards Dietary Intake. J Nutri Health. 2016;2(2): 12.

ISSN: 2469-4185

Table 6: Overview of precautionary practices for minimizing PAHs and HAAs intake.

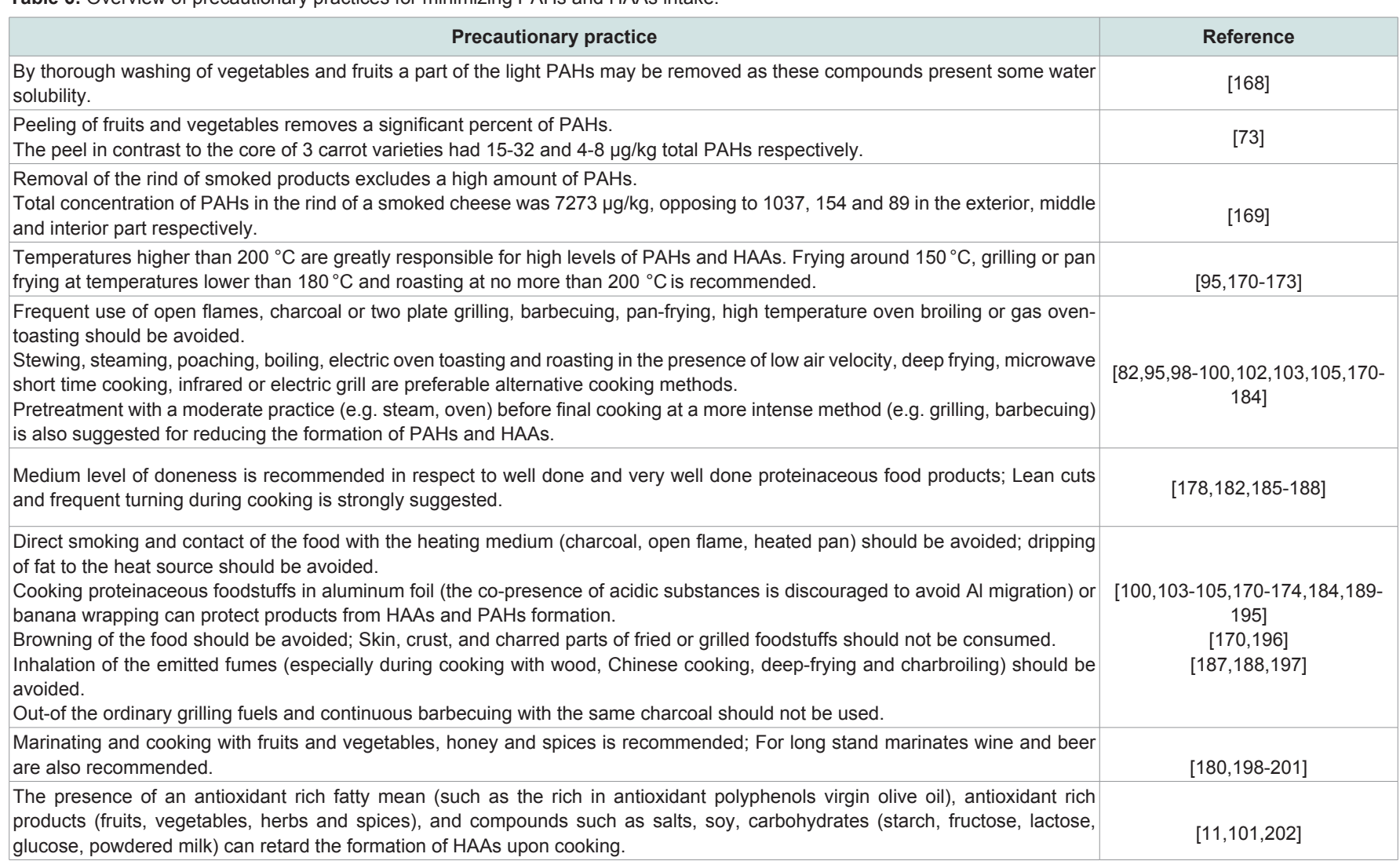

vulnerable groups (pregnant, breast feeding women, infants and children) are the receptors. This meaning seems to have passed to consumers as only organic baby products have not followed the descending trend as a coherence of economic crisis outbreaks [79].

On the other hand there are alternative ways to reduce the levels of pesticide residues from contaminated crops and prevent relative negative health effects $[69,70]$. The extensive literature review on pesticide residue elimination due to food processing of Kaushik and co-workers [69], as well as the meta-analysis review of Keikotlhaile et al. that summarizes the effects of food processing on pesticide residue levels, present that processing leads to significant reductions in residue levels in the final foodstuff, particularly through washing, peeling, thermal treatments applied and preserving [70]. Other practices that are reported to reduce pesticide residues but are beyond the scope of this study are bread making, dairy product manufacture, drying, fermentation, malting, milling, parboiling and wine making [69]. Of course, the physicochemical characteristics of the food, the type of pesticides present, the pesticides' age on the product, treatment conditions employed, along with other parameters, affect residues removal patterns from burdened foodstuffs [69]. In Table 5 simple practices to reduce pesticides residues intake are summarized. At this point it should be mentioned that some practices recommended for the reduction of pesticides residues, for example peeling, juicing and thermal treating, may also decrease nutritionally important ingredients such as vitamins, antioxidants and fibers.

\section{Polycyclic aromatic hazards dietary intake prevention}

Polycyclic aromatic hydrocarbons (PAHs) are a group of compounds, products of combustion and pyrolysis. PAHs bear two or more fused aromatic rings without hetero-atoms or substituents. They are classified to "light" and "heavy" compounds containing up to four or more than four fused benzene rings, respectively. The latter are considered more stable and more harmful [80,81]. The toxicity of PAHs has been well documented and is mainly related to carcinogenicity, cardiovascular diseases, peripheral arterial disease and other severe disorders [82-84]. Sources of human exposure are environmental burdens (natural and anthropogenic), tobacco smoke, and diet. Diet is the main non-occupational source of PAHs to nonsmoking population, estimated to contribute with a more than $90 \%$ of the total PAHs exposure. Food is burdened with PAHs through environmental pollution $[80,85,86]$. Incomplete burning of materials consisting of carbon, such as oil, wood, garbage, coal leads to their formation. Foodstuffs are mainly burdened with PAHs during industrial processing (mainly heating, drying and smoking) and cooking practices (mainly barbecuing, grilling, frying and roasting) and to a lesser extend via their contact with contaminated materials [80]. Practices that allow combustion products to come into direct contact with food are mainly responsible for PAHs formation. The most prone to PAHs contamination foodstuffs are meat and meat products, oils and fats, bread and relevant products, dairy products, nuts and crops, fish products, as well as smoked foodstuffs [87-90]. In order to protect public health from PAHs risk, maximum levels in certain foods have been set by the EC regulation [25]. Foods designated for consumption by infants and young children are set to the lower level of $1 \mu \mathrm{g} / \mathrm{kg}$ wet foodstuff weight. 
Citation: Papoti VT, Mourtzinos I, Adamidis T. Preventive Practices from Field and Shelf to Fork to Minimize Chemical Hazards Dietary Intake. J Nutri Health. 2016;2(2): 12.

ISSN: $2469-4185$

As PAHs are lipophylic compounds they can easily accumulate to high fat containing foods such as smoked cheese. It is important to point out that the higher percentages of cancer incidents reported for young people (mainly breast cancer incidents) in some African countries have been related to diets employing high PAHs intake due to smoked products frequent consumption [87]. Such findings reveal that in countries were smoked foodstuffs are an important part of the traditional diet there is an urgent need to educate for safe smoking processes that will ensure lower PAHs levels in relevant foodstuffs [87]. Another critical issue concerns the relation of PHAs exposure of fetuses and infants with reproductive and developmental problems [91]. Breast feeding of heavy smoking mothers especially when also residing in urban regions poses serious risks [92].

Heterocyclic aromatic amines (HAAs) is another group of polycyclic aromatic hazards formed during the high thermal treatment of food, and being related to similar serious health risks to PAHs $[11,93]$. In processed food products they are regularly found along with PAHs. HAAs are mutagenic and carcinogenic compounds mainly found in cooked proteinaceous food such as meat and fish However, they may also appear in other food products for example pan residues, soup cubes, meat drippings, processed flavors, sauces, cheese products, coffee, alcoholic beverages, etc. [94]. They are usually formed via the Maillard reaction and are considered probable or reasonably anticipated to be human carcinogens, with some regarded mutagenically hundred and thousand-fold more active (Ames test) than the strongly mutagens aflatoxin B1 and benz(a)pyrene. Still some of the most frequent HAAs, such as harman and norharman, are not considered mutagenic, but their presence augments the mutagenicity of other harmful HAAs [11,93-96]. Up to now more than 25 harmful HAAs have been found to be formed during the heating processes of various food products. They are heterocyclic molecules with one or more nitrogen atoms in their aromatic rings (2-5) and they often contain one exocyclic amino group. HAAs are mainly classified in two categories according to the temperature at which they are formed; the "thermic" ones or amino-imidazo-azarenes formed around $100-300$ ${ }^{\circ} \mathrm{C}$, and the "pyrolytic" ones or aminocarbolines formed over $300{ }^{\circ} \mathrm{C}$ Frequently HAAs are also distinguished to polar and non-polar ones [94]. No matter their well established harmful activity [97] maximum levels for HAAs have not been established, yet.

In brief, food origin, nature and composition, food fat content, cooking method, temperature, time, pretreatment practices, frequency of food turning during cooking, presence and content of other compounds, as well as level of doneness, among others, strongly affect PAHs and HAAs formation [82,98-105]. In Table 6 proven practices for minimizing PAHs and HAAs intake are presented.

\section{Conclusion}

Simply practices such as controlled thermal treatments, washing in certain conditions and proper handling of raw material, can remarkably reduce the levels of certain chemical hazards leading to safer foodstuffs. Moreover common salty, acidic or basic solutions or incorporation of natural antioxidants upon food pretreatment and cooking can significantly reduce the levels of the examined hazards. All treatments are precautionary practices addressed to consumers, professionals and anyone involved at any stage of food production and handling from farm to fork. Such practices can be incorporated in home and professional kitchens, as well as in quality systems of restaurants, canteens, food industries, storehouses of producers, distributers, selling points, etc. When the object of subject is safer foodstuffs and a healthier wellbeing relevant knowledge, positive attitude and good practice are mandatory.

\section{References}

1. Sharif L, Al-Malki T (2010) Knowledge, attitude and practice of Taif University students on food poisoning. Food Control 21: 55-60.

2. Losasso C, Cibin V, Cappa V, Roccato A, Vanzo A, et al. (2012) Food safety and nutrition: improving consumer behaviour. Food Control 26: 252-258.

3. Fantke $P$, Friedrich $R$, Jolliet $O$ (2012) Health impact and damage cost assessment of pesticides in Europe. Environ Int 49: 9-17.

4. Lazou T, Georgiadis M, Pentieva K, McKevitt A, Iossifidou E (2012) Food safety knowledge and food-handling practices of Greek university students: a questionnaire-based survey. Food Control 28: 400-411.

5. Farahat MF, El-Shafie MM, Waly MI (2015) Food safety knowledge and practices among Saudi women. Food Control 47: 427-435.

6. Alagidede P, Alagidede AN (2016) The public health effects of water and sanitation in selected West African countries. Public Health 130: 59-63.

7. Dorevitch S, Babin A (2001) Health hazards of ceramic artists. Occup Med 16: 563-575.

8. Riederer AM, Shine JP, Danan LM, Ford TE (2005) Concentrations of lead and mercury in multimedia samples from homes near the former Clark Air Base, Philippines. Sci Total Environ 341: 53-69.

9. Łozowicka B, Jankowska M, Kaczyński P (2012) Pesticide residues in Brassica vegetables and exposure assessment of consumers. Food Control 25: 561-575.

10. Freire C, Amaya E, Fernández MF, González-Galarzo MC, Ramos R, et al. (2011) Relationship between occupational social class and exposure to organochlorine pesticides during pregnancy. Chemosphere 83: 831-838.

11. Ferguson LR (2010) Meat and cancer. Meat Sci 84: 308-313.

12. Umesh CG, Subhas CG (2011) Heavy metal toxicity in humans and its preventive and control measures. Curr Nutr Food Sci 7: 221-231.

13. Sharma RK, Agrawal M (2005) Biological effects of heavy metals: an overview. J Environ Biol 26(2 Suppl): 301-313.

14. Kapaj S, Peterson H, Liber K, Bhattacharya P (2006) Human health effects from chronic arsenic poisoning--a review. J Environ Sci Health A Tox Hazard Subst Environ Eng 41: 2399-2428.

15. Tchounwou PB, Ayensu WK, Ninashvili N, Sutton D (2003) Environmental exposure to mercury and its toxicopathologic implications for public health Environ Toxicol 18: 149-175.

16. Järup L (2003) Hazards of heavy metal contamination. Br Med Bull 68: 167182

17. Suruchi, Khanna P (2011) Assessment of heavy metal contamination in different vegetables grown in and around urban areas. Res J Environ Toxicol 5: $162-179$

18. Bolle F, Brian W, Petit D, Boutakhrit K, Feraille G, et al. (2011) Tea brewed in traditional metallic teapots as a significant source of lead, nickel and other chemical elements. Food Addit Contam Part A Chem Anal Control, Expo Risk Assess 28: 1287-1293.

19. Belgaied JE (2003) Release of heavy metals from Tunisian traditiona earthenware. Food Chem Toxicol 41: 95-98.

20. Sheets RW (1998) Release of heavy metals from European and Asian porcelain dinnerware. Sci Total Environ 212: 107-113.

21. Ai-Ashmawy MA (2011) Prevalence and public health significance of aluminum residues in milk and some dairy products. J Food Sci 76: T73-T76. 
Citation: Papoti VT, Mourtzinos I, Adamidis T. Preventive Practices from Field and Shelf to Fork to Minimize Chemical Hazards Dietary Intake. J Nutri Health. 2016;2(2): 12.

ISSN: $2469-4185$

22. Kumar R, Srivastava PK, Srivastava SP (1994) Leaching of heavy metals ( $\mathrm{Cr}$, $\mathrm{Fe}$, and $\mathrm{Ni}$ ) from stainless steel utensils in food simulants and food materials. Bull Environ Contam Toxicol 53: 259-266.

23. Rose M, Baxter M, Brereton N, Baskaran C (2010) Dietary exposure to metals and other elements in the 2006 UK total diet study and some trends over the last 30 years. Food Addit Contam Part A Chem Anal Control Expo Risk Assess 27: 1380-1404.

24. Tuzen M, Soylak M (2007) Evaluation of trace element contents in canned foods marketed from Turkey. Food Chem 102: 1089-1095.

25. 835/2011 CrEn Commission regulation (EU) no. 835/2011 of 19 August 2011 amending regulation (EC) no. 1881/2006 as regards maximum levels for polycyclic aromatic hydrocarbons in foodstuffs. Official Journal of the European Union 215/4

26. Aikoh H, Nishio MR (1996) Aluminum content of various canned and bottled beverages. Bull Environ Contam Toxicol 56: 1-7

27. Waheed S, Rahman S, Husnain SM, Siddique N (2012) Hazardous and other element characterization of new and used domestic plastic food containers using INAA and AAS. J Radioanaly Nucl Chem 292: 937-945

28. Rafique U, Iqbal S, Faiz S, Hashmi A (2009) Analysis of variation in concentration of essential and non essential elements in canned and fresh food. J Food Process Pres 33: 186-203.

29. Muller JP, Steinegger A, Schlatter C (1993) Contribution of aluminium from packaging materials and cooking utensils to the daily aluminium intake. Z Lebensm Unters Forsch 197: 332-341.

30. Rajwanshi P, Singh V, Gupta MK, Dass S (1997) Leaching of aluminium from cookwares -- a review. Environ Geochem Health 19.

31. Uluozlu OD, Tuzen M, Mendil D, Soylak M (2007) Trace metal content in nine species of fish from the Black and Aegean Seas, Turkey. Food Chem 104: 835-840.

32. Ab Razak NH, Praveena SM, Aris AZ, Hashim Z (2016) Quality of Kelantan drinking water and knowledge, attitude and practice among the population of Pasir Mas, Malaysia. Public Health 131: 103-111.

33. Lei B, Chen L, Hao Y, Cao T, Zhang X, et al. (2013) Trace elements in animalbased food from Shanghai markets and associated human daily intake and uptake estimation considering bioaccessibility. Ecotoxicol Environ Saf 96 160-167.

34. Martena MJ, van der Wielen JC, Rietjens IM, Klerx WN, De Groot HN, et al. (2010) Monitoring of mercury, arsenic, and lead in traditional Asian herbal preparations on the Dutch market and estimation of associated risks. Food Addit Contam Part A Chem Anal Control Expo Risk Assess 27: 190-205.

35. Li Z, Ma Z, van der Kuijp TJ, Yuan Z, Huang L (2014) A review of soil heavy metal pollution from mines in China: pollution and health risk assessment. Sci Total Environ 468-469: 843-853.

36. Li Q, Chen Y, Fu H, Cui Z, Shi L, et al. (2012) Health risk of heavy metals in food crops grown on reclaimed tidal flat soil in the Pearl River Estuary, China. J Hazard Mater 227-228: 148-154.

37. Zhuang P, Zou B, Li NY, Li ZA (2009) Heavy metal contamination in soils and food crops around Dabaoshan mine in Guangdong, China: implication for human health. Environ Geochem Health 31: 707-715.

38. Amin N-u, Hussain A, Alamzeb S, Begum S (2013) Accumulation of heavy metals in edible parts of vegetables irrigated with waste water and their daily intake to adults and children, District Mardan, Pakistan. Food Chem 136: 1515-1523.

39. Mahmood A, Malik RN (2014) Human health risk assessment of heavy metals via consumption of contaminated vegetables collected from different irrigation sources in Lahore, Pakistan. Arabian J Chem 7: 91-99.

40. Kalogeropoulos N, Karavoltsos S, Sakellari A, Avramidou S, Avramidoua S, et al. (2012) Heavy metals in raw, fried and grilled Mediterranean finfish and shellfish. Food Chem Toxicol 50: 3702-3708.

41. Ersoy B (2011) Effects of cooking methods on the heavy metal concentrations of the african catfish (clarias gariepinus). J Food Biochem 35: 351-356.
42. Maulvault AL, Anacleto P, Loureno HM, Carvalho ML, Nunes ML, et al. (2012) Nutritional quality and safety of cooked edible crab (Cancer pagurus). Food Chem 133: 277-283.

43. Maulvault AL, Anacleto P, Machado R, Amaral A, Carvalho ML, et al. (2012) Effect of sex, maturation stage and cooking methods on the nutritional quality and safety of black scabbard fish (Aphanopus carbo Lowe, 1839). J Sci Food Agric 92: 1545-1553.

44. Diaconescu C, Fantaneru G, Urdes L, Stefan D (2013) Influence of cooking methods over the heavy metal and lipid content of fish meat. Rom Biotechnol Lett 18: 8279-8283.

45. Talab AS, Jahin HS, Gaber SE, Ghannam HE (2014) Influence of modern cooking techniques on heavy metals concentrations of some freshwater fish fillets. Res J Appl Sci Eng Technol 8: 69-75.

46. Ouédraogo O, Amyot M (2011) Effects of various cooking methods and food components on bioaccessibility of mercury from fish. Environ Res 111: 10641069.

47. Perugini M, Visciano P, Manera M, Abete MC, Gavinelli S, et al. (2013) Contamination of different portions of raw and boiled specimens of Norway lobster by mercury and selenium. Environ Sci Pollut Res Int 20: 8255-8262.

48. Musaiger AO, D'Souza R (2008) The effects of different methods of cooking on proximate, mineral and heavy metal composition of fish and shrimps consumed in the Arabian Gulf. Arch Latinoam Nutr 58: 103-109.

49. Galitsopoulou A, Georgantelis D, Kontominas MG (2013) Effect of thermal processing and canning on cadmium and lead levels in California market squid: the role of metallothioneins. Food Addit Contam Part A Chem Anal Control Expo Risk Assess 30: 1900-1908.

50. Amiard JC, Amiard-Triquet C, Charbonnier L, Mesnil A, Rainbow PS, et al (2008) Bioaccessibility of essential and non-essential metals in commercial shellfish from Western Europe and Asia. Food Chem Toxicol 46: 2010-2022.

51. Kyzas GZ (2012) Commercial coffee wastes as materials for adsorption of heavy metals from aqueous solutions. Materials 5: 1826-1840.

52. Meena AK, Bansal P, Kumar S, Rao MM, Garg VK (2010) Estimation of heavy metals in commonly used medicinal plants: a market basket survey. Environ Monit Assess 170: 657-660.

53. Kadir MM, Janjua NZ, Kristensen S, Fatmi Z, Sathiakumar N (2008) Status of children's blood lead levels in Pakistan: implications for research and policy. Public Health 122: 708-715.

54. Smith EA, Prues SL, Oehme FW (1996) Environmental degradation of polyacrylamides. 1. Effects of artificial environmental conditions: temperature, light, and pH. Ecotoxicol Environ Saf 35: 121-135.

55. Ghasemian S, Rezaei K, Abedini R, Poorazarang H, Ghaziani F (2014) Investigation of different parameters on acrylamide production in the fried beef burger using Taguchi experimental design. J Food Sci Technol 51: 440448.

56. SNFA (2002) Swedish National Food Administration. Information about Acrylamide in Food

57. Wyka J, Tajner-Czopek A, Broniecka A, Piotrowska E, Bronkowska M, et al (2015) Estimation of dietary exposure to acrylamide of Polish teenagers from an urban environment. Food Chem Toxicol 75: 151-155.

58. Miller MJ, Carter DE, Sipes IG (1982) Pharmacokinetics of acrylamide in Fisher-344 rats. Toxicol Appl Pharmacol 63: 36-44.

59. Viswanath $P$ (2012) Evaluation of certain contaminants in food (Seventysecond report of the Joint FAO/WHO Expert Committee on Food Additives). Indian J Med Res 135: 795-796.

60. Powers SJ, Mottram DS, Curtis A, Halford NG (2013) Acrylamide concentrations in potato crisps in Europe from 2002 to 2011. Food Addit Contam Part A Chem Anal Control Expo Risk Assess 30: 1493-1500.

61. Magkos F, Arvaniti F, Zampelas A (2006) Organic food: buying more safety or just peace of mind? A critical review of the literature. Crit Rev Food Sci Nutr 46: 23-56. 
Citation: Papoti VT, Mourtzinos I, Adamidis T. Preventive Practices from Field and Shelf to Fork to Minimize Chemical Hazards Dietary Intake. J Nutri Health. 2016;2(2): 12.

ISSN: 2469-4185

62. Rekha, Naik SN, Prasad R (2006) Pesticide residue in organic and conventional food-risk analysis. J Chem Health Saf 13: 12-19.

63. Fenik J, Tankiewicz M, Biziuk M (2011) Properties and determination of pesticides in fruits and vegetables. TrAC Trends Analyt Chem 30: 814-826.

64. Sannino A (2008) Pesticide residues. In: Pico Y (Ed). Comprehensive analytical chemistry: Food contaminants and residue analysis. Elsevier, London, 51: 257-302.

65. George J, Shukla Y (2011) Pesticides and cancer: insights into toxicoproteomic-based findings. J Proteomics 74: 2713-2722.

66. Mostafalou S, Abdollahi M (2013) Pesticides and human chronic diseases: evidences, mechanisms, and perspectives. Toxicol Appl Pharmacol 268: $157-177$

67. Nougadère A, Reninger JC, Volatier JL, Leblanc JC (2011) Chronic dietary risk characterization for pesticide residues: a ranking and scoring method integrating agricultural uses and food contamination data. Food Chem Toxicol 49: 1484-1510

68. Akoto O, Andoh H, Darko G, Eshun K, Osei-Fosu P (2013) Health risk assessment of pesticides residue in maize and cowpea from Ejura, Ghana Chemosphere 92: 67-73

69. Kaushik G, Satya S, Naik SN (2009) Food processing a tool to pesticide residue dissipation - A review. Food Res Int 42: 26-40.

70. Keikotlhaile BM, Naert M, Spanoghe P (2010) Behaviour of pesticide residues in selected vegetables after domestic steaming. Commun Agric Appl Biol Sc 75: 239

71. Latif Y, Sherazi ST, Bhanger MI (2011) Assessment of pesticide residues in commonly used vegetables in Hyderabad, Pakistan. Ecotoxicol Environ Saf 74: 2299-2303.

72. Wang HS, Sthiannopkao S, Du J, Chen ZJ, Kim KW, et al. (2011) Daily intake and human risk assessment of organochlorine pesticides (OCPs) based on Cambodian market basket data. J Hazard Mater 192: 1441-1449.

73. Zohair A, Salim AB, Soyibo AA, Beck AJ (2006) Residues of polycyclic aromatic hydrocarbons (PAHs), polychlorinated biphenyls (PCBs) and organochlorine pesticides in organically-farmed vegetables. Chemosphere 63: $541-553$

74. Malmauret L, Parent-Massin D, Hardy JL, Verger P (2002) Contaminants in organic and conventional foodstuffs in France. Food Addit Contam 19: 524 532

75. Faller AL, Fialho E (2010) Polyphenol content and antioxidant capacity in organic and conventional plant foods. J Food Compost Anal 23: 561-568.

76. Ordónẽz-Santos LE, Vázquez-Odériz ML, Romero-Rodríguez MA (2011) Micronutrient contents in organic and conventional tomatoes (Solanum lycopersicum L.). Int J Food Sci Technol 46: 1561-1568.

77. Raigón MD, Rodríguez-Burruezo A, Prohens J (2010) Effects of organic and conventional cultivation methods on composition of eggplant fruits. J Agric Food Chem 58: 6833-6840.

78. Zhao X, Chambers E 4th, Matta Z, Loughin TM, Carey EE (2007) Consumer sensory analysis of organically and conventionally grown vegetables. J Food Sci 72: S87-S91.

79. Falguera V, Aliguer N, Falguera M (2012) An integrated approach to current trends in food consumption: moving toward functional and organic products? Food Control 26: 274-281.

80. Plaza-Bolaños P, Frenich AG, Vidal JL (2010) Polycyclic aromatic hydrocarbons in food and beverages. Analytical methods and trends. J Chromatogr A 1217: 6303-6326.

81. Wenzl T, Simon R, Anklam E, Kleiner J (2006) Analytical methods for polycyclic aromatic hydrocarbons (PAHs) in food and the environment needed for new food legislation in the European Union. TrAC Trends Anal Chem 25: 716-725

82. Anderson KE, Sinha R, Kulldorff M, Gross M, Lang NP, et al. (2002) Meat intake and cooking techniques: associations with pancreatic cancer. Muta Res 506-507: 225-231.
83. Straif K, Baan R, Grosse Y, Secretan B, El Ghissassi F, et al. (2005) Carcinogenicity of polycyclic aromatic hydrocarbons. Lancet Oncol 6: 931932.

84. Xu X, Hu H, Kearney GD, Kan H, Sheps DS (2013) Studying the effects of polycyclic aromatic hydrocarbons on peripheral arterial disease in the United States. Sci Total Environ 461-462: 341-347.

85. Khillare PS, Jyethi DS, Sarkar S (2012) Health risk assessment of polycyclic aromatic hydrocarbons and heavy metals via dietary intake of vegetables grown in the vicinity of thermal power plants. Food Chem Toxicol 50: 16421652.

86. Khillare PS, Sarkar S (2012) Airborne inhalable metals in residential areas of Delhi, India: distribution, source apportionment and health risks. Atmos Pollut Res 3: 46-54.

87. Essumang DK, Dodoo DK, Adjei JK (2012) Polycyclic aromatic hydrocarbon (PAH) contamination in smoke-cured fish products. J Food Compost Anal 27: 128-138.

88. Martorell I, Perelló G, Martí-Cid R, Castell V, Llobet JM, et al. (2010) Polycyclic aromatic hydrocarbons (PAH) in foods and estimated PAH intake by the population of Catalonia, Spain: Temporal trend. Environ Int 36: 424432

89. Phillips DH (1999) Polycyclic aromatic hydrocarbons in the diet. Mutat Res 443: 139-147.

90. Veyrand B, Sirot V, Durand S, Pollono C, Marchand P, et al. (2013) Human dietary exposure to polycyclic aromatic hydrocarbons: results of the second French Total Diet Study. Environ Int 54: 11-17.

91. Perera FP, Rauh V, Whyatt RM, Tang D, Tsai WY, et al. (2005) A summary of recent findings on birth outcomes and developmental effects of prenatal ETS, $\mathrm{PAH}$, and pesticide exposures. Neurotoxicology 26: 573-587.

92. Zanieri L, Galvan P, Checchini L, Cincinelli A, Lepri L, et al. (2007) Polycyclic aromatic hydrocarbons (PAHs) in human milk from Italian women: influence of cigarette smoking and residential area. Chemosphere 67: 1265-1274.

93. Ferguson LR (2010) Dietary influences on mutagenesis--where is this field going? Environ Mol Mutagen 51: 909-918.

94. Alaejos MS, Afonso AM (2011) Factors that affect the content of heterocyclic aromatic amines in foods. Comprehensive Reviews in Food Science and Food Safety 10: 52-108

95. Skog K, Solyakov A (2002) Heterocyclic amines in poultry products: a literature review. Food Chem Toxicol 40: 1213-1221.

96. Lee KG, Shibamoto T (2002) Toxicology and antioxidant activities of nonenzymatic browning reaction products: review. Food Rev Int 18: 151-175.

97. EFSA (2008) Scientific opinion of the panel on contaminants in the food chain on a request from the European Commission on polycyclic aromatic hydrocarbons in food. EFSA J 724: 1-114.

98. Chung SY, Yettella RR, Kim JS, Kwon K, Kim MC, et al. (2011) Effects of grilling and roasting on the levels of polycyclic aromatic hydrocarbons in beef and pork. Food Chem 129: 1420-1426.

99. Dost K, İdeli C (2012) Determination of polycyclic aromatic hydrocarbons in edible oils and barbecued food by HPLC/UV-Vis detection. Food Chem 133: 193-199.

100. Farhadian A, Jinap S, Hanifah HN, Zaidul IS (2011) Effects of meat preheating and wrapping on the levels of polycyclic aromatic hydrocarbons in charcoal-grilled meat. Food Chem 124: 141-146.

101. Janoszka B (2011) HPLC-fluorescence analysis of polycyclic aromatic hydrocarbons (PAHs) in pork meat and its gravy fried without additives and in the presence of onion and garlic. Food Chem 126: 1344-1353.

102. Perelló G, Martí-Cid R, Castell V, Llobet JM, Domingo JL (2009) Concentrations of polybrominated diphenyl ethers, hexachlorobenzene and polycyclic aromatic hydrocarbons in various foodstuffs before and after cooking. Food Chem Toxicol 47: 709-715.

103. Rey-Salgueiro L, García-Falcón MS, Martínez-Carballo E, Simal-Gándara 
Citation: Papoti VT, Mourtzinos I, Adamidis T. Preventive Practices from Field and Shelf to Fork to Minimize Chemical Hazards Dietary Intake. J Nutri Health. 2016;2(2): 12.

ISSN: 2469-4185

$\mathrm{J}$ (2008) Effects of toasting procedures on the levels of polycyclic aromatic hydrocarbons in toasted bread. Food Chem 108: 607-615.

104. Santos C, Gomes A, Roseiro LC (2011) Polycyclic aromatic hydrocarbons incidence in Portuguese traditional smoked meat products. Food Chem Toxicol 49: 2343-2347.

105. Viegas O, Novo P, Pinto E, Pinho O, Ferreira IM (2012) Effect of charcoal types and grilling conditions on formation of heterocyclic aromatic amines (HAs) and polycyclic aromatic hydrocarbons (PAHs) in grilled muscle foods. Food Chem Toxicol 50: 2128-2134.

106. Liukkonen-Lilja H, Piepponen S (1992) Leaching of aluminium from aluminium dishes and packages. Food Addit Contam 9: 213-223.

107. Seruga M, Grgic J, Grgic Z, Seruga B (1997) Aluminium content of beers. Z Lebensm Unters Forsch A 204: 221-226.

108. Kassouf A, Chebib H, Lebbos N, Ouaini R (2013) Migration of iron, lead cadmium and tin from tinplate-coated cans into chickpeas. Food Addit Contam Part A Chem Anal Control Expo Risk Assess 30: 1987-1992.

109. Ranau R, Oehlenschläger J, Steinhart H (2001) Aluminium levels of fish fillets baked and grilled in aluminium foil. Food Chem 73: 1-6.

110. Demertzis PG (2012) Evaluation of safety of recycled paper and board food contact materials. Food Packaging: Procedures, Management and Trends, pp. 133-172.

111. Regulation EN EC No $1935 / 2004$ of the European Parliament and of the Council of 27 October 2004 on materials and articles intended to come into contact with food and repealing Directives 80/590/EEC and 89/109/EEC Official Journal of the European Union L 338/4.

112. Barbee SJ, Constantine LA (1994) Release of lead from crystal decanters under conditions of normal use. Food Chem Toxicol 32: 285-288.

113. Hight SC (1996) Lead migration from lead crystal wine glasses. Food Addit Contam 13: 747-765.

114. Council Directive of 15 October 1984 on the approximation of the laws of the Member States relating to ceramic articles intended to come into contact with foodstuffs (84/500/EEC). OJ L 277: 12.

115. Hamurcu M, Özcan MM, Dursun N, Gezgin S (2010) Mineral and heavy metal levels of some fruits grown at the roadsides. Food Chem Toxicol 48 1767-1770.

116. Roychowdhury $T$, Tokunaga $H$, Ando M (2003) Survey of arsenic and other heavy metals in food composites and drinking water and estimation of dietary intake by the villagers from an arsenic-affected area of West Bengal, India. Sci Total Environ 308: 15-35.

117. Sengupta MK, Hossain MA, Mukherjee A, Ahamed S, Das B, et al. (2006) Arsenic burden of cooked rice: Traditional and modern methods. Food Chem Toxicol 44: 1823-1829.

118. Mihucz VG, Silversmit G, Szalóki I, de Samber B, Schoonjans T, et al (2010) Removal of some elements from washed and cooked rice studied by inductively coupled plasma mass spectrometry and synchrotron based confocal micro-X-ray fluorescence. Food Chem 121: 290-297.

119. Copat C, Arena G, Fiore M, Ledda C, Fallico R, et al. (2013) Heavy metals concentrations in fish and shellfish from eastern Mediterranean Sea: consumption advisories. Food Chem Toxicol 53: 33-37.

120. Hajeb P, Jinap S (2009) Effects of washing pre-treatment on mercury concentration in fish tissue. Food Addit Contam Part A Chem Anal Contro Expo Risk Assess 26: 1354-1361.

121. Ryan JA, Pahren HR, Lucas JB (1982) Controlling cadmium in the human food chain: a review and rationale based on health effects. Environ Res 28 251-302.

122. Morgan JN (1999) Effects of processing on heavy metal content of foods Adv Exp Med Biol 459: 195-211.

123.EPA (2013) Drinking water best management practices: For schools and child care facilities served by municipal water systems. United States Environmental Protection Agency.
124. Mateo R, Rodríguez-de la Cruz M, Vidal D, Reglero M, Camarero P (2007) Transfer of lead from shot pellets to game meat during cooking. Sci Total Environ 372: 480-485

125. Nabulo G, Black CR, Craigon J, Young SD (2012) Does consumption of leafy vegetables grown in peri-urban agriculture pose a risk to human health? Environ Pollut 162: 389-398.

126. Gökmen V, Palazoğlu TK, Şenyuva HZ (2006) Relation between the acrylamide formation and time-temperature history of surface and core regions of French fries. J Food Eng 77: 972-976.

127. Matthäus B, Haase NU, Vosmann K (2004) Factors affecting the concentration of acrylamide during deep-fat frying of potatoes. Eur $\mathrm{J}$ Lipid Sci Technol 106: 793-801.

128. Williams JS (2005) Influence of variety and processing conditions on acrylamide levels in fried potato crisps. Food Chem 90: 875-881.

129. Özkaynak E, Ova G (2009) Effects of various cooking conditions on acrylamide formation in rolled patty. Food Addit Contam Part A Chem Anal Control Expo Risk Assess 26: 793-799.

130. Chuda Y, Ono H, Yada H, Ohara-Takada A, Matsuura-Endo C, et al. (2003) Effects of physiological changes in potato tubers (Solatium tuberosum L.) after low temperature storage on the level of acrylamide formed in potato chips. Biosci Biotechnol Biochem 67: 1188-1190.

131. Vinci RM, Mestdagh F, De Meulenaer B (2012) Acrylamide formation in fried potato products - Present and future, a critical review on mitigation strategies. Food Chem 133: 1138-1154.

132. Pedreschi F, Kaack K, Granby K, Troncoso E (2007) Acrylamide reduction under different pre-treatments in French fries. J Food Eng 79: 1287-1294.

133. Hendriksen HV, Kornbrust BA, Ernst S, Stringer MA (2005) Asparaginase mediated reduction of acrylamide formation in baked, fried, and roasted products. J Biotechnol 118: 135-135.

134. Kita A, Bråthen E, Knutsen SH, Wicklund T (2004) Effective ways of decreasing acrylamide content in potato crisps during processing. J Agric Food Chem 52: 7011-7016.

135. Kolek E, Šimko P, Simon P (2006) Inhibition of acrylamide formation in asparagine/d-glucose model system by $\mathrm{NaCl}$ addition. Eur Food Res Technol 224: 283-284.

136. Pedreschi F, Granby K, Risum J (2009) Acrylamide mitigation in potato chips by using $\mathrm{NaCl}$. 5th International Technical Symposium on Food Processing, Monitoring Technology in Bioprocesses and Food Quality Management, pp. $63-68$

137. Yuan Y, Huanjie Z, Yutian M, Hong Z (2014) Study on the methods for reducing the acrylamide content in potato slices after microwaving and frying processes. RSC Adv 4: 1004-1009.

138. Cheng KW, Shi JJ, Ou SY, Wang M, Jiang Y (2010) Effects of fruit extracts on the formation of acrylamide in model reactions and fried potato crisps. $J$ Agric Food Chem 58: 309-312.

139. Kotsiou K, Tasioula-Margari M, Kukurová K, Ciesarová Z (2010) Impact of oregano and virgin olive oil phenolic compounds on acrylamide content in a model system and fresh potatoes. Food Chem 123: 1149-1155.

140. Pastoriza S, Rufián-Henares JA, Morales FJ (2012) Reactivity of acrylamide with coffee melanoidins in model systems. LWT - Food Sci Technol 45: 198203.

141. Zhu F, Cai YZ, Ke J, Corke H (2009) Evaluation of the effect of plant extracts and phenolic compounds on reduction of acrylamide in an asparagine/ glucose model system by RP-HPLC-DAD. J Sci Food Agric 89: 1674-1681.

142. Oral RA, Dogan M, Sarioglu K (2014) Effects of certain polyphenols and extracts on furans and acrylamide formation in model system, and total furans during storage. Food Chem 142: 423-429.

143. Granda C, Moreira RG, Tichy SE (2004) Reduction of acrylamide formation in potato chips by low-temperature vacuum frying. J Food Sci 69: E405-E411.

144. Taubert D, Harlfinger S, Henkes L, Berkels R, Schömig E (2004) Influence 
Citation: Papoti VT, Mourtzinos I, Adamidis T. Preventive Practices from Field and Shelf to Fork to Minimize Chemical Hazards Dietary Intake. J Nutri Health. 2016;2(2): 12.

ISSN: 2469-4185

of processing parameters on acrylamide formation during frying of potatoes. J Agric Food Chem 52: 2735-2739.

145. Gupta VK, Gupta B, Rastogi A, Agarwal S, Nayak A (2011) Pesticides removal from waste water by activated carbon prepared from waste rubber tire. Water Res 45: 4047-4055

146.Zhang X, Guo Q, Shen X, Yu S, Qiu G (2015) Water quality, agriculture and food safety in China: Current situation, trends, interdependencies, and management. J Integr Agric 14: 2365-2379.

147. Abou-Arab AA (1999) Behavior of pesticides in tomatoes during commercia and home preparation. Food Chem 65: 509-514

148. Guardia-Rubio M, Ayora-Cañada MJ, Ruiz-Medina A (2007) Effect of washing on pesticide residues in olives. J Food Sci 72: C139-C143.

149. Liang Y, Wang W, Shen Y, Liu Y, Liu XJ (2012) Effects of home preparation on organophosphorus pesticide residues in raw cucumber. Food Chem 133: 636-640.

150.Soliman KM (2001) Changes in concentration of pesticide residues in potatoes during washing and home preparation. Food Chem Toxicol 39: 887-891.

151. Yang A, Park JH, Abd El-Aty AM, Choi JH, Oh JH, et al. (2012) Synergistic effect of washing and cooking on the removal of multi-classes of pesticides from various food samples. Food Control 28: 99-105.

152.Zhang ZY, Liu XJ, Hong XY (2007) Effects of home preparation on pesticide residues in cabbage. Food Control 18: 1484-1487.

153. Burchat CS, Ripley BD, Leishman PD, Ritcey GM, Kakuda Y, et al. (1998) The distribution of nine pesticides between the juice and pulp of carrots and tomatoes after home processing. Food Addit Contam 15: 61-71.

154. Liang Y, Liu Y, Ding Y, Liu XJ (2014) Meta-analysis of food processing on pesticide residues in fruits. Food Addit Contam Part A Chem Anal Contro Expo Risk Assess 31: 1568-1573.

155. Awasthi MD (1993) Decontamination of insecticide residues on mango by washing and peeling. J Food Sci Technol 30: 132-133.

156. Holland PT, Hamilton D, Ohlin B, Skidmore MW (1994) Effects of storage and processing on pesticide residues in plant products. IUPAC Reports on Pesticides (31). Pure Appl Chem 66: 335-356.

157. Rasmussen RR, Poulsen ME, Hansen HC (2003) Distribution of multiple pesticide residues in apple segments after home processing. Food Addit Contam 20: 1044-1063.

158. Balinova AM, Mladenova RI, Shtereva DD (2006) Effects of processing on pesticide residues in peaches intended for baby food. Food Addit Contam 23: 895-901.

159. Bonnechere A, Hanot V, Bragard C, Bedoret T, van Loco J (2012) Effect of household and industrial processing on the levels of pesticide residues and degradation products in melons. Food Addit Contam Part A Chem Anal Control Expo Risk Assess 29: 1058-1066.

160. Kovacova J, Kocourek V, Kohoutkova J, Lansky M, Hajslova J (2014) Production of apple-based baby food: changes in pesticide residues. Food Addit Contam Part A Chem Anal Control Expo Risk Assess 31: 1089-1099.

161. Kong Z, Shan W, Dong F, Liu X, Xu J, et al. (2012) Effect of home processing on the distribution and reduction of pesticide residues in apples. Food Addit Contam Part A Chem Anal Control Expo Risk Assess 29: 1280-1287.

162. Tewary DK, Kumar V, Ravindranath SD, Shanker A (2005) Dissipation behavior of bifenthrin residues in tea and its brew. Food Control 16: 231-237.

163. Kumar V, Sood C, Jaggi S, Ravindranath SD, Bhardwaj SP, et al. (2005) Dissipation behavior of propargite --an acaricide residues in soil, apple (Malus pumila) and tea (Camellia sinensis). Chemosphere 58: 837-843.

164. Kontou S, Tsipi D, Tzia C (2004) Stability of the dithiocarbamate pesticide maneb in tomato homogenates during cold storage and thermal processing Food Addit Contam 21: 1083-1089.

165.Zhang H, Lu Y (2007) End-users' knowledge, attitude, and behavior towards safe use of pesticides: a case study in the Guanting Reservoir area, China Environ Geochem Health 29: 513-520.

166. Karaka H, Velioglu YS (2007) Ozone applications in fruit and vegetable processing. Food Rev Int 23: 91-106.

167. Wu J, Luan T, Lan C, Hung Lo TW, Chan GY (2007) Removal of residual pesticides on vegetable using ozonated water. Food Control 18: 466-472.

168. Tfouni SA, Souza NG, Neto MB, Loredo IS, Leme FM, et al. (2009) Polycyclic aromatic hydrocarbons (PAHs) in sugarcane juice. Food Chem 116: 391 394

169. Guillén MD, Sopelana P (2004) Occurrence of polycyclic aromatic hydrocarbons in smoked cheese. J Dairy Sci 87: 556-564.

170. Fretheim K (1983) Polycyclic aromatic hydrocarbons in grilled meat products-A review. Food Chem 10: 129-139.

171.Lijinsky W (1991) The formation and occurrence of polynuclear aromatic hydrocarbons associated with food. Mutat Res 259: 251-261.

172. Wild D (1996) Heterocyclic amines. New and yet old unwanted substances. Fleischwirtschaft 76: 42-45.

173.Zimmerli B, Rhyn P, Zoller O, Schlatter J (2001) Occurrence of heterocyclic aromatic amines in the Swiss diet: analytical method, exposure estimation and risk assessment. Food Addit Contam 18: 533-551.

174. Gasperlin L, Lukan B, Zlender B, Polak T (2009) Effects of skin and grilling method on formation of heterocyclic amines in chicken pectoralis superficialis muscle. Food Sci Technol 42: 1313-1319.

175. Oz F, Kaban G, Kaya M (2010) Effects of cooking methods and levels on formation of heterocyclic aromatic amines in chicken and fish with Oasis extraction method. LWT - Food Sci Technol 43: 1345-1350.

176. Oz F, Kaban G, Kaya M (2010) Heterocyclic aromatic amine contents of beef and lamb chops cooked by different methods to varying levels. J Anim Vet Adv 9: 1436-1440.

177. Oz F, Kaban G, Kaya M (2010) Effects of cooking techniques and levels on the formation of heterocyclic aromatic amines in chicken and fish. J Anim Vet Adv 9: 1259-1264

178. Puangsombat K, Gadgil P, Houser AT, Hunt MC, Smith JS (2012) Occurrence of heterocyclic amines in cooked meat products. Meat Sci 90: 739-746.

179. Warzecha L, Janoszka B, Błaszczyk U, Strózyk M, Bodzek D, et al. (2004) Determination of heterocyclic aromatic amines (HAs) content in samples of household-prepared meat dishes. J Chromatogr B Analyt Technol Biomed Life Sci 802: 95-106

180. Farhadian A, Jinap S, Faridah A, Zaidul IS (2012) Effects of marinating on the formation of polycyclic aromatic hydrocarbons (benzo[a]pyrene, benzo[b]fluoranthene and fluoranthene) in grilled beef meat. Food Control 28: $420-425$.

181. Felton JS, Fultz E, Dolbeare FA, Knize MG (1994) Effect of microwave pretreatment on heterocyclic aromatic amine mutagens/carcinogens in fried beef patties. Food Chem Toxicol 32: 897-903.

182. Kazerouni N, Sinha R, Hsu CH, Greenberg A, Rothman N (2001) Analysis of 200 food items for benzo[a]pyrene and estimation of its intake in an epidemiologic study. Food Chem Toxicol 39: 423-436.

183. Orecchio S, Papuzza V (2009) Levels, fingerprint and daily intake of polycyclic aromatic hydrocarbons (PAHs) in bread baked using wood as fuel. J Hazard Mater 164: 876-883.

184. Wakabayashi K, Nagao M, Esumi H, Sugimura T (1992) Food-derived mutagens and carcinogens. Cancer Res 52(7 Suppl): S2092-S2098.

185. Sinha R, Knize MG, Salmon CP, Brown ED, Rhodes D, et al. (1998) Heterocyclic amine content of pork products cooked by different methods and to varying degrees of doneness. Food Chem Toxicol 36: 289-297.

186. Sinha R, Rothman N, Salmon CP, Knize MG, Brown ED, et al. (1998) Heterocyclic amine content in beef cooked by different methods to varying degrees of doneness and gravy made from meat drippings. Food Chem Toxicol 36: 279-287. 
Citation: Papoti VT, Mourtzinos I, Adamidis T. Preventive Practices from Field and Shelf to Fork to Minimize Chemical Hazards Dietary Intake. J Nutri Health. 2016;2(2): 12.

ISSN: 2469-4185

187. Abdullahi KL, Delgado-Saborit JM, Harrison RM (2013) Emissions and indoo concentrations of particulate matter and its specific chemical components from cooking: a review. Atmos Environ 71: 260-294.

188. Berg I, Overvik E, Gustafsson JA (1990) Effect of cooking time on mutagen formation in smoke, crust and pan residue from pan-broiled pork. Food Chem Toxicol 28: 421-426.

189. Abdulkarim BG, Smith JS (1998) Heterocyclic amines in fresh and processed meat products. J Agric Food Chem 46: 4680-4687.

190.Borgen E, Skog K (2004) Heterocyclic amines in some Swedish cooked foods industrially prepared or from fast food outlets and restaurants. Mo Nutr Food Res 48: 292-298.

191. Murkovic M, Pfannhauser W (2000) Analysis of the cancerogenic heterocyclic aromatic amines in fried meat. Fresenius' J Anal Chem 366: 375-378.

192. Salmon CP, Knize MG, Panteleakos FN, Wu RW, Nelson DO, et al. (2000) Minimization of heterocyclic amines and thermal inactivation of Escherichia coli in fried ground beef. J Natl Cancer Inst 92: 1773-1778.

193.Solyakov A, Skog K (2002) Screening for heterocyclic amines in chicken cooked in various ways. Food Chem Toxicol 40: 1205-1211.

194. Steinmann R, Fischer A (2000) Heterocyclic aromatic amines (HAA) in German meat loaf. Fleischwirtschaft 80: 93-98.

195. Weisburger JH (2002) Comments on the history and importance of aromatic and heterocyclic amines in public health. Mutat Res 506-507: 9-20.
196. Saint-Aubert B, Cooper JF, Astre C, Spiliotis J, Joyeux H (1992) Evaluation of the induction of polycyclic aromatic hydrocarbons $(\mathrm{PAH})$ by cooking on two geometrically different types of barbecue. J Food Compos Anal 5: 257263.

197. Adetona O, Li Z, Sjödin A, Romanoff LC, Aguilar-Villalobos M, et al. (2013) Biomonitoring of polycyclic aromatic hydrocarbon exposure in pregnant women in Trujillo, Peru--comparison of different fuel types used for cooking. Environ Int 53: 1-8.

198. Lan CM, Chen BH (2002) Effects of soy sauce and sugar on the formation of heterocyclic amines in marinated foods. Food Chem Toxicol 40: 989-1000.

199. Lan CM, Kao TH, Chen BH (2004) Effects of heating time and antioxidants on the formation of heterocyclic amines in marinated foods. J Chromatogr $B$ Analyt Technol Biomed Life Sci 802: 27-37.

200. Salmon CP, Knize MG, Felton JS (1997) Effects of marinating on heterocyclic amine carcinogen formation in grilled chicken. Food Chem Toxicol 35: 433441.

201. Salmon CP, Knize MG, Felton JS, Zhao B, Seow A (2006) Heterocyclic aromatic amines in domestically prepared chicken and fish from Singapore Chinese households. Food Chem Toxicol 44: 484-492.

202. Oguri A, Suda M, Totsuka Y, Sugimura T, Wakabayashi K (1998) Inhibitory effects of antioxidants on formation of heterocyclic amines. Mutat Res 402 : 237-245.A 